\title{
Comparative analysis of public policies in open access models in Latin America. Brazil and Argentina cases
}

\author{
Karen Isabel Cabrera Peña \\ Doctoral student in Law at the University of El Rosario, Colombia | kicabrerap@gmail.com
}

Submitted in: September 2013

Accepted in: February 2014

Published in: January 2015

\section{Recommended citation}

Cabrera, K.I. (2015). Comparative analysis of public policies in open access models in Latin America. Brazil and Argentina cases. RUSC. Universities and Knowledge Society Journal, 12(1). pp. 15-24. doi http://doi.dx.org/10.7238/rusc.v12i1.1947

\begin{abstract}
This article presents public policies for open access models in Argentina and Brazil, two countries that have pioneered the subject in Latin America. The methodology used is comparative documentation, whereby the legal and political frameworks of open access systems are contrasted, paying special attention to the education, science, culture and government sectors. The main conclusion is that, in spite of technological and legal difficulties, public policies provide accessible information and quality knowledge.
\end{abstract}

\section{Keywords}

policies, models, open access, knowledge

\section{Análisis comparativo de políticas públicas en modelos de acceso abierto en América Latina. El caso de Brasil y Argentina}

\section{Resumen}

Este artículo presenta las políticas públicas en modelos de acceso abierto en Argentina y Brasil, países pioneros en el tema, como ejemplos del desarrollo en América Latina. La técnica de investigación implementada es la comparación. Se interrelaciona el marco legal y político de los sistemas de acceso abierto en cada uno de los países de estudio, desde los campos de educación, ciencia, cultura y gobierno. Se concluye que los procesos de políticas públicas, a pesar de las dificultades tecnológicas y legales, proveen y masifican la información y el conocimiento de calidad.

\section{Palabras clave}

políticas, modelos, acceso abierto, conocimiento 


\section{Introduction}

Free access to cultural and scientific information is the main process to generate new knowledge, a key factor in $21^{\text {st }}$-century society. When knowledge access is endorsed, the economic, political and cultural barriers among regions are reduced (Arencibia Jorge, 2006).

The dissemination and broadcasting of scientific, academic and cultural advances has changed: previously, the only efficient way of spreading the information was through books and periodical journals and publications. Currently, with the development and growth of the Internet and other information technologies, new ways of publication and innovative formulas to access knowledge have been created (Parada, 2005).

It is in this context where "open access" is born, to allow free access to readers through digital and online versions of scientific articles. The underlying premise is that information can be used by several sources as long as a legitimate and non-commercial use of the work is made and the authorship of its creators is recognized (Parada, 2005). This initiative was later expanded to open educational resources (OER), open government data and access policies to galleries, libraries, archives and museums.

The first precedent found is The Open Access Initiative, signed in Budapest, which defines "free availability on the public internet, permitting any users to read, download, copy, distribute, print, search, or link to the full texts of these articles, [...] or use them for any other lawful purpose, without financial, legal, or technical barriers other than those inseparable from gaining access to the internet itself" (Open Access Initiative, 2002). Later, in 2003, this initiative was ratified by the Bethesda Statement (April $11^{\text {th }}$ ) and the Berlin Declaration (October ${ }^{\text {th }}$ ) (Rosen, 2012).

At the same time, several countries have developed open access initiatives -for scientific and academic information- through the design of legal tools such as legislative proposals and other public policies. Latin American countries like Argentina and Brazil have built relatively solid open access systems, not only in areas like science, but also in culture and education.

\section{Legal and political framework of open access}

The constant and fast changes of information and communication technologies (ICT) in recent years have introduced more efficient and dynamic ways to process information, which in turn has facilitated access to intellectual production (Arencibia Jorge, 2006).

Although the importance of introducing instruments that allow access is manifest, legal limitations that hinder these initiatives are ever present, such as intellectual property. In the case of industrial property, there are private companies that own patents and can restrict access to their content for a specified time (Landes \& Posner, 2003); also, in the case of copyright, there are requirements for anyone wanting to access and share information. These include obtaining the owner's approval and providing full author identification to acknowledge the work, and in some cases paying fees or licenses to access it (Plata López, 2010). This indicates that the vast majority of resources that are digitally accessed are subject to rights and ownership, and therefore tools that respect and balance the interests of both creators and knowledge promotion must be introduced.

In line with the above, public administrations have had to develop projects that provide the legal framework for the technological, economic and legal conditions under which digital information can be accessed and its content controlled (Iglesias \& Labastida, 2006). In this context, "open" indicates the possibility of using digital resources 
such as data, scientific production results, educational material or cultural manifestations, without any payment or charge, through technological instruments such as interoperable or standard formats, which vary depending on the requirements built or developed for each type of resource. These resources also include the permits and legal characteristics enabling them to be published and disseminated on the Web (Arencibia Jorge, 2006).

Today, in order to implement open access public policies, national states have based their behavior on the premise that, in order to spread resources in a flexible way, it is important to manage the copyright of the circulating contents, which implies generating authorizations to negotiate copyright of the works that involve reproduction, communication, distribution and modification, such that liability for breach of copyright can be avoided; in order to solve these problems, open access policies have created general authorizations, given that individual authorization would involve a large amount of time and money (Iglesias \& Labastida, 2006).

These authorizations are often granted in cases where the business or economic sustainability model does not depend on the transaction or the author's permission, such as intellectual works that are sponsored by public resources and where the author's compensation is to be credited by the state in exchange for the research results.

In other cases, as time passes or because of limitations or exceptions in the law, the owner's control over his/her work is reduced to some extent, thus turning it into a work in the public domain. This means that anyone can access it without prior authorization. Hence the importance of pointing out that the permit for copyright of the work can be used through obligatory and legal licenses which allow, under certain circumstances, the use of the contents (Lipszyc, 1993).

\section{Method: comparative analysis of "openness"}

The comparative model of open access policies will be based on four areas where legal mechanisms have been developed:

\begin{tabular}{|l|l|l|}
\hline \multicolumn{1}{|c|}{ Area } & $\begin{array}{c}\text { Name acquired by } \\
\text { the "open" element }\end{array}$ & \multicolumn{1}{c|}{ Basic description } \\
\hline Education & $\begin{array}{l}\text { Open Educational } \\
\text { Resources (OER) }\end{array}$ & $\begin{array}{l}\text { Open content focused on education. It must be free and comply with technological standards of } \\
\text { interoperability and legal authorizations so that the content can be published, spread and downloaded } \\
\text { from the Internet (reproduction, distribution and public communication) (UNESCO, 2009). }\end{array}$ \\
\hline Science & Open Access & $\begin{array}{l}\text { Open access is defined as the free and public availability on the Web, allowing any user to read, } \\
\text { download, copy, distribute, print, search or link to full texts without economic, legal or technical } \\
\text { barriers. Therefore, technological standards of interoperability and legal authorizations, standards of } \\
\text { reproduction, distribution and public communication are implied, except for the content (Parada, 2005). }\end{array}$ \\
\hline Government & $\begin{array}{l}\text { Open Government } \\
\text { Culture }\end{array}$ & $\begin{array}{l}\text { A series of techniques aimed at optimizing communication between the government and the } \\
\text { citizens to achieve a dynamic, collaborative, effective and efficient dialog, where new information } \\
\text { technologies play a significant role. This is developed through an "open access" strategy intended } \\
\text { to share public data as a transparency exercise, without charge and under certain technological } \\
\text { (accessible data) and legal standards (Clavijo, 2011). }\end{array}$ \\
\hline $\begin{array}{l}\text { Open Glam (Galleries, } \\
\text { Libraries, Archives, and } \\
\text { Museum) }\end{array}$ & $\begin{array}{l}\text { It proposes open policies for Galleries, Libraries, Archives and Museums. The cultural field has been } \\
\text { focusing, as has the government field, in contents and open access strategies. This is the most recent } \\
\text { and complex open access, given its wide spectrum. }\end{array}$ \\
\hline
\end{tabular}


The previous definitions were developed in both Argentina and Brazil, from a techno-centric angle, meaning the way in which access through technological advances is facilitated. This explains the vision of not having standards that clearly delimit the way of making the data technologically and legally accessible available. However, besides allowing access to these sources, the re-use of this data has also been facilitated (Arencibia Jorge, 2006).

Within each country's relevant legal framework, it is possible to establish the parameters regarding the dissemination and broadcasting of intellectual property that is commonly financed by public resources. Likewise, the comparative model will enable reflection on the measures that these countries have adopted so that, within legal standards, the copyrighted material can be accessed and re-used.

The exploration was based on the analysis of politics and the idea of "public goods".'

\section{A. Science: Open Access}

\section{Argentina}

a. Creation of Open Digital Repositories of Science and Technology, OPEN SCIENCE ARGENTINA: This initiative was presented to Congress given the low rate of contents registered in digital repositories, which prompted a policy that encouraged the openness of intellectual production (Bongiovani \& Nakano, 2010).

In 2011, the National System of Digital Repositories was created (Spanish acronym SNRD), which drives and coordinates an interoperable web of repositories physically distributed on a website. This is managed by institutions or a group of institutions on a national level to increase the visibility and impact of Argentina's scientific and technological production, through free access to read, download, copy, distribute, print, search and link the scientific texts and use them for legitimate purposes of research and education (National System of Digital Repositories, 2012).

b. Open Access Bill: This Bill is intended to secure the open access publication of research that has been financed primarily by the state budget, in an electronic format based on the National System of Digital Repositories (Rosen, 2012).

The Bill indicates that the deposits must be made in the institutional repositories, within a period no longer than six months after being published or approved (Science, Technology and Productive Innovation Department, 2010).

\section{Brazil}

a. Open Access Bill: In spite of being the first Latin American country to present initiatives on this subject, Brazil has been held back due to the presidential cycle of 2010. This proposal intends to enable access to documents resulting from research financed by public resources (Ortellado, 2009).

b. Salvador Declaration (2005), the Brazilian Manifest in support of Open Access (2008) and the São Paulo Letter: These recommendations tend to promote equitable access and control over information and knowledge as an essential condition for the country's development. Several public universities -like the University of Brasilia- have

1. The definition of Elinor Ostrom (1990) of a public good: "A good that is available to all and the use by a person not subtracted the use by others." The most important characteristic is digital resources because they have objects not depletable that are abundant. 
adopted open repository systems. Likewise, the Brazilian Institute of Science and Technology (BICT) has developed a system to allow visibility and open access to its journals (Brazilian Portal of Open Access and Scientific Information, 2009).

\section{Preliminary results}

- Open Access in science has progressed along a very specific course; the research results that are published in indexed journals are disseminated, and a standard that measures the quality of the research and the impact of the public investment in the area has been established.

- Public policy is prone to issue mandates of self-archiving in institutional or themed repositories that fulfill technological standards, of sharing information, of avoiding breach of copyright laws and of making sure that the content is published online for free one year after being published at the latest. Usually there are no provisions regarding re-using the material, although it is easily facilitated (open licensing).

- These mandates increasingly stem from the law, and their scope may be related to the resources devoted by a specific organization -or line of research- to establish publishing mandates.

- There is a strong tension between those who are in favor of open access and those who are inclined to production and dissemination models based on the control of the product (industry). Because of this, open access has developed a very specific scenario relating to indexed journals.

- Taking into account that there are policies of diverse levels in relation to open access and science, it is clear that success is associated with the level of commitment. The fact that the Brazilian Bill was hindered by the political process demonstrates that without political commitment it is very hard to move a legislative initiative forward.

- The tendency to develop a policy that links the mandate to a repository network that facilitates and monitors its compliance follows on from lessons learned from the pioneer initiatives. Studies have shown that the tendency is to create voluntary deposits with repositories and host networks.

\section{B. Education: Open Educational Resources (OER)}

\section{Argentina}

Educ.ar, Educational Portal of Argentina: This proposal from the Ministry of Education seeks to articulate Argentina's education and technology policies through a philosophy of sharing. However, there is no current project on the development of material with OER standards. This project is part of a regional program, the Latin American Network of Educational Portals (RELPE), which seeks to garner regional contents to increase access to these types of materials (Educational Portal of Argentina, 2010).

\section{Brazil}

a. Bill 1513 of 2011: This initiative stipulates that educational resources that are financed with Federal Government money have to be published with open licenses to enable access. It also clarifies that the research produced by public servants should be published in the open access framework, while promoting government support for federated systems that distribute and archive these resources. This initiative is being replicated by São Paulo State (Vollme, 2011). 
b. Educational Resources, financed by the Department of Education of São Paulo under the Creative Commons license: The Municipal Department of Education of São Paulo adopted the Creative Commons license AttributionNoncommercial-ShareAlike (BY-NC-SA) for all of its educational and teaching material. It pertains to a legal disposition or mandate that becomes effective through the publication of resources made available on its Internet portal (Municipal Department of Education of São Paulo, 2010).

\section{Preliminary results}

- Unlike the science sector, the development model of teaching materials is wide-ranging; most of its resources come from the public sector, but the need to adjust them to local and even individual needs suggests that a more decentralized and diverse model could work better.

- The public policy trend has been emphasized in cooperation projects between institutions to share educational resources. Currently, there are few mandates that seek public investment to make public research materials available.

- To ensure that educational resources can be re-used, the mandates must be more careful and diverse, since the population and the objective of each project must be taken into account.

- There are diverse repository initiatives supported by the public sector, and willing to embrace open educational resources. However, as in the science sector, these become truly effective and logical once they are associated with mandates.

- Public policy in this matter seems to be more successful when it is closely linked to established communities; hence, there are few legal orders of this sort and there are more executive decisions on how public money should be spent, creating obligations on the recipients.

- There is no clear public policy model yet, since the diversity of teaching products is large, which hinders clear principles regarding the subject.

- Most of the projects involve investment and cooperation; the state proposes mechanisms for cooperation among the institutions providing material (and financing) to the education sector and support to the host repository networks.

\section{Culture: Open Glam}

\section{Argentina}

a. SEDECI Agreement - Wikimedia Argentina: SEDECl is the institutional repository of the University of La Plata Library (public institution), which signed an agreement with Wikimedia Argentina to digitalize public domain books on a massive scale and upload them to Wikimedia Commons, for which a specialized scanner will be delivered. The project will spread to another three cultural institutions that also have that objective (SEDECI, 2012).

b. Cultural access through the Internet: Bill 1927 D-2011 is a new initiative that seeks to facilitate:

... access to authors' works or their use via the Internet by an individual in the privacy of the home, in schools, universities, libraries and free public access areas, with the sole purpose of learning, educating, informing, entertaining or inspiring, excluding any form of commercial use or public use thereof. This initiative constitutes the exercise of the right

RUSC VOL. 12 No 1 | Universitat Oberta de Catalunya and University of New England | Barcelona, January 2015 
to access culture and, in no case can making a single copy of a digital file on a personal computer be construed as an unlawful act if the content is meant to be used for non-commercial or non-profit purposes. It will not be punishable to facilitate such access when it is offered free of charge to the user. (Bill 1927 D-2011, 2012, Article 1)

\section{Brazil}

"Digital Culture" Agenda: During the government of President Lula Da Silva, an integral look at culture -especially creativity- was promoted, as was a laboratory set up to search for new sustainability models developed through programs such as cultural and digital centers in impoverished districts, which would become artistic production laboratories by taking advantage of the Internet (Rohter, 2007). These digital policies articulate a flexible approach to how to take advantage of technology and legal system changes (especially copyright) to reinforce the ability to provide access and democratize digital technology. This political line was abandoned by the current government (Lemos, 2011).

\section{Preliminary results}

- Public policies of openness in culture have focused on thinking, from within the government, about how to manage those cultural products on which it has an influence, which are usually public or primarily financed with public money.

- The premises in place for the cultural area are completely different from the ones taken into account in other areas and most of the obstacles stem from the law itself. For this reason, the central concern is that it seems easy to implement, in terms of the standardization of technological terms, but in legal terms more authorizations are needed.

- The main idea behind the project is to promote institutional cooperation to deal with difficulties relating to the interpretation of the law: When is public domain material being addressed? What is the range of exceptions and limitations on copyright to favor library and archive access? How can new Bills be promulgated to solve the weak points and contradictions that affect the area?

- When it is possible to identify and explain the law to favor the cultural sector and its projects, the result is the dissemination of the material in the public domain, which, because of its characteristics, facilitates a wide access to the hosted resources.

- A clear public policy will achieve fundamental modifications to the law to solve weak points and problems. However, given the distinctive features of current law and the tensions that changes in digital technology generate, it is foreseeable that the regulation will not be put together soon.

\section{Government: Open Data}

\section{Argentina}

Buenos Aires Data Project: It is a Buenos Aires city initiative that seeks to implement an open government policy on data-related issues, following the $156^{\text {th }}$ Decree of 2012. It pertains to a group of techniques that seek to optimize communication between the government and the citizens to achieve a dynamic, collaborative, effective and efficient dialog, where ICT play a significant role. The technical process of implementing Open Data results in the 
creation of a technology that leads to efficiencies in the government's public data, over different levels (federal, provincial and municipal), so that they can be open and be re-used by a third party (Arellano, 2011).

\section{Brazil}

Dados.gov.br: This project is an initiative of the Planning Ministry of Brazil, together with the Open Knowledge Foundation (OKFN) to develop a website where public data will be available to the general public. The site is licensed in accordance with Creative Commons Attribution-ShareAlike and was launched in May 2012 with over 80 data groups and 893 resources. The project develops guidelines stemming from the Access to Public Information Bill and the Decree that set forth the Open Government Action Plan (Secretaria de Logística e Tecnologia da Informação, 2010).

\section{Preliminary results}

- The government initiatives resemble those of the science sector, because the production model is globally similar. This is a very recent trend that has been made possible thanks to ICT, which have developed over the past decades.

- Open government responds to a need of greater transparency and audit tools for citizens, which is possible through digital technology.

- Unlike the science sector, implementation provokes reflections about copyright management and other regulations (such as confidentiality) to guarantee that what is shared is public and widely re-used, a feature that puts it closer to the education sector.

\section{Conclusions}

Openness in Argentina: The Argentinean public sector is making progress down the legislative path to drive open ideas, becoming regional pioneers in this matter.

As regards the projects' scope, in all of the areas apart from culture, an imposition of conditions over public resources can be recognized, which demonstrates a compilation of European and American experiences.

It is not yet possible to provide a precise report of the projects' challenges and achievements, among other reasons because these are recent initiatives and there is little discussion around them.

Openness in Brazil: It is possible to identify that public support for open access has acquired a special meaning through legal provisions, such as the OER case, where unlike other countries, it is regulated by law. The projects show a direct leaning towards open access, as open licenses are being adopted.

The proposed initiatives are justified in the context of social communities that are driving this trend; however, given the new government's lack of political commitment to some of these initiatives, some have not been able to be implemented.

\section{Final considerations}

As evidenced by the laws and policies implemented by the states, the objective of "openness" is to facilitate and expand access to foster development through knowledge and culture, which enables our societies to address problems by adopting new and diverse solutions. 
Even though there are still difficulties in addressing this topic due to legal and technological control restrictions, the truth is that the improvements are aimed at enabling access, starting with open policies. Bearing in mind that there are standardization issues for re-use that are more demanding and broader than the public access ones, open access models imply the use of documents under a Creative Commons license or a similar agreement that permits a more liberal use (including redistribution) than the traditional principles of fair usage.

\section{References}

Abadal, E. (2012). Acceso abierto a la ciencia. Barcelona: Editorial UOC (Colección El profesional de la información). Anteproyecto de ley "La creación de repositorios digitales abiertos de ciencia y tecnología", Honorable Cámara de la Nación, 19 October 2010.

Area Moreira, M. (2011). ¿Qué opina el profesorado sobre el Programa Escuela 2.0? Avance de resultados. Madrid: Ministerio de Ciencia e Innovación.

Arellano, J. (18 March 2011). La nueva sociedad civil en Latinoamerica. Retrieved from http://informacioncivica.info/ mexico-2/el-movimiento-open-data-en-latinoamerica/

Arencibia Jorge, R. (2006). Las iniciativas para el acceso abierto a la información científica en el contexto de la Web Semántica. Biblios: Revista electrónica de bibliotecología, archivología y museología, 2(25-26), 1-14.

Bongiovani, P. C., \& Nakano, S. (2010). El Sistema Nacional de Repositorios Digitales (SNRD). La experiencia de articulación y coordinación institucional de los repositorios digitales en ciencia y tecnología. Jornada Virtual del Acceso Abierto Argentina 2010 (pp. 1-12). Buenos Aires: e- Colabora.

Clavijo, V. (2011). SerDigital. Retrieved from http://www.serdigital.cl/2011/10/26/open-data-de-gobiernos/

Concha, G., \& Naser, A. (2012). El desafío hacia el gobierno abierto en la hora de la igualdad. Comisión Económica para América Latina y el Caribe (CEPAL).

Craveiro, G., Machado, J., \& Ortellado, P. (2008). El mercado de libros técnicos y científicos en Brasil. São Paulo: Canal 6 Projetos Editoriais.

El portal educativo del Estado Argentino. (2010). Educ.ar. Retrieved from http://www.educ.ar/

Iglesias, C., \& Labastida, I. (2006). Guía sobre gestión de derechos de autor y acceso abierto a bibliotecas, servicios de documentación y archivos. Madrid: Asociación Española de Documentación e Información.

Iniciativa de Acceso abierto (1 March 2002). Organización Soros. Retrieved from http://www.soros.org/openaccess/ translations/spanish-translation

Landes, W. M., \& Posner, R. A. (2003). The structure of intellectual property law. Massachusetts: The Belknap Press.

Lemos, R. (March 2011). A Legacy at Risk: How the new Ministry of Culture in Brazil reversed its digital agenda. Freedom to Tinker.

Lipszyc, D. (1993). Derecho de autory derechos conexos. Cerlalc: Ediciones Unesco.

Ortellado, P. (2009). Acceso abierto en Brasil. São Paulo: GPOPAl.

Ostrom, E. (1990). Governing the Commons: The Evolution of Institutions for Collective Action. Cambridge: Cambridge University Press. doi http://dx.doi.org/10.1017/CBO9780511807763

Parada, A. (2005). El acceso abierto (open access) y el futuro de la edición en el ámbito biomédico: una figura con múltiples aristas. El profesional de la información, 14(5), 326-334. doi http://dx.doi.org/10.3145/epi.2005.sep.02

Plata López, L. C. (2010). Responsabilidad civil por infracciones al derecho de autor. Barranquilla: Grupo editorial Ibañez - Ediciones Uninorte. 
Portal Brasilero de acceso abierto e información científica. (2009). Todo sobre oasisbr. Ibict.

Proyecto de ley 1927 D-2011 (11 May 2012). Buenos Aires.

Rodrigues, E. (8 June 2009). Kit de políticas de acceso abierto. Retrieved from http://es.scribd.com/doc/58025440/

Kit-de-politicas-de-Acceso-Abierto

Rohter, L. (12 March 2007). Gilberto Gil and the politics of music. The New York Times.

Rosen, C. (7 June 2012). Red ciencia y desarrollo. Retrieved from http://www.scidev.net/es/science-communication/ open-access/news/argentina-avanza-hacia-una-ley-de-acceso-abierto.html

Secretaria de Logística e Tecnologia da Informação. (2010). Dados. Retrieved from http://dados.gov.br/

Secretaria Municipal de Educación de São Paulo. (2010). Portal da Prefeitura da Cidade de São Paulo. Retrieved from

http://www.portalsme.prefeitura.sp.gov.br/anonimo/quemsomos/quemsomos.aspx?MenulD=165

SEDECI. (10 August 2012). Servicio de Difusión de la Creación Intelectual. Retrieved from http://sedici.unlp.edu.ar/blog/ Sistema Nacional de Repositorios Digitales (1 April 2012). Retrieved from http://repositorios.mincyt.gob.ar/adhesion.

php

Unión Internacional de Telecomunicaciones (22 February 2012). Retrieved from http://www.itu.int/es/about/Pages/ default.aspx

UNESCO. (2009). Open Educational Resources: Conversations in Cyberspace. UNESCO.

Viñas, M. (2010). Las fronteras del acceso abierto en las bibliotecas. Buenos Aires: Universidad Nacional de La Plata.

Vollme, T. (15 July 2011). Creative Commons. Brazil introduces OER into federal legislation and adopts local government policy. Retrieved from http://creativecommons.org/weblog/entry/27698

\section{About the author}

\section{Karen Isabel Cabrera Peña}

kicabrerap@gmail.com

Doctoral student in Law at the University of El Rosario, Colombia

Graduate in Law from the Universidad del Norte, Colombia. Doctoral student in Law at the University of El Rosario, Colombia. Researcher in the Karisma Foundation's Law, Internet and Society (LIS) group. Visiting Scholar at Washington College of Law, American University, USA.

Universidad del Rosario

Calle 12, núm. 6-25

Bogotá

Colombia

Original title Análisis comparativo de políticas públicas en modelos de acceso abierto en América Latina. El caso de Brasil y Argentina

@) SOIME RIGHIS RESERNED
The texts published in this journal are - unless indicated otherwise - covered by the Creative Commons Spain Attribution 3.0 licence. You may copy, distribute, transmit and adapt the work, provided you attribute it (authorship, journal name, publisher) in the manner specified by the author(s) or licensor(s). The full text of the licence can be consulted here: <http://creativecommons.org/licenses/by/3.0/es/deed.en>

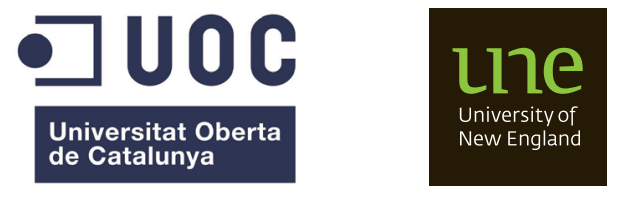

RUSC VOL. 12 No 1 | Universitat Oberta de Catalunya and University of New England | Barcelona, January 2015 @ Karen Isabel Cabrera | @ 2015 by FUOC | Comparative analysis of public policies in open access models in Latin America. Brazil and Argentina cases 